\title{
Relationship between the Onset of Winter and Collared Lemming Abundance at Churchill, Manitoba, Canada: 1932-90
}

\author{
PETER A. SCOTT
}

\author{
(Received 9 June 1992; accepted in revised form 14 October 1992)
}

\begin{abstract}
Ten periods of high abundance and nine periods of low abundance of collared lemmings (Dicrostonyx richardsani) at Churchill, Manitoba, Canada, were determined from 1932 to 1990 using published and unpublished trapping studies. Response functions were used to relate extremes of lemming abundance to temperature and precipitation in the preceding 24 months. Good correspondence was found between conditions around fall freeze-up and both high and low collared lemming abundance. This indicates that far-from-average temperature and precipitation may moderate the abundance of collared lemmings. During spring and fall the southern tundra, such as at Churchill, has a high frequency of annual freeze-thaw cycles, indicating that this area may be more stressful to lemmings than cooler climates with fewer freeze-thaw cycles.
\end{abstract}

Key words: Churchill, Manitoba, collared lemmings, cycles, freeze-thaw, temperature, precipitation, freezing rain, snow cover

RÉSUMÉ. De 1932 à 1990, on a déterminé 10 périodes de forte abondance et 9 périodes de basse abondance de lemmings à collerette (Dicrostonyx richardsoni) à Churchill (Manitoba), au Canada, en se servant d'études publiées ou inédites sur le piégeage. On a utilisé les fonctions de réponse pour relier les extrêmes d'abondance de lemmings à la température et aux précipitations durant les 24 mois précédents. On a trouvé qu'il existait une correspondance intéressante entre les conditions de l'engel automnal et la forte comme la faible abondance des lemmings à collerette. Cela indique que des températures et des précipitations nettement différentes de la moyenne peuvent influer sur l'abondance des lemmings à collerette. Au cours du printemps et de l'automne, la fréquence des cycles annuels de gel et dégel est élevée dans la toundra méridionale, comme celle qui se trouve à Churchill, ce qui révèle que cette région peut être plus stressante pour les lemmings que d'autres situées dans des climats plus froids ayant moins de cycles de gel et dégel.

Mots clés : Churchill, Manitoba, lemmings à collerette, cycles, gel et dégel, température, précipitation, pluie verglaçante, couvert nival

Traduit pour le journal par Nésida Loyer.

\section{INTRODUCTION}

Few studies in Canada involve direct determination of mammal abundance over a long period (e.g., Mihok et al., $1985)$. Churchill, Manitoba $\left(58^{\circ} 45^{\prime} \mathrm{N}, 94^{\circ} 05^{\prime} \mathrm{W}\right)$ has been an active site for both time series studies of mammal fur abundance (Elton and Nicholson, 1942) and early 20th-century small mammal trappings (Preble, 1902). Since the 1920s summer trapping of collared lemmings (Dicrostonyx richardsoni) at Churchill has been almost continuous (Shelford and Twomey, 1941; Shelford, 1943; Smith and Foster, 1957; Foster, 1961; Quay, 1969; Brooks, 1970; Wrigley, 1974; Scott, 1988; Scott and Hansell, 1989). In trapping reports, specific field seasons are noted by either the high abundance or the rarity of lemmings (cf. Steen et al., 1990).

The Shelford (1943) study at Churchill related weather conditions to the abundance of collared lemmings during 1929-40 and suggested that deep snow and warm summer temperatures are favourable for high numbers of collared lemmings. It was also argued that high rainfall in late summer could cause unfavourable winter conditions in lowland areas, forcing collared lemmings into upland areas with less snow cover and, thus, colder temperatures. The inference is that unfavourable conditions at fall freeze-up may either delay the occurrence of peak numbers of lemmings or reduce the small mammal density during the peak.

In time series applications such as tree ring studies, response functions are developed to quantify the biological response to weather influences (Fritts, 1976). Response function analysis entails correlation of monthly temperature and precipitation during the growth year (i.e., year of high or low abundance) and during the previous year (Fritts, 1976). The analysis allows for ranking of variable importance in the make-up of the time series, which can be assembled into a predictive model and tested (e.g., Gray et al., 1981; Gray and Pilcher, 1983). The application of this method has been expanded to predict successfully the important periods in the growing season of northern trees (Scott $e t$ al., 1988). Application of this method could be useful in determining the weather influences on the timing of collared lemming abundance.

During this study I examine trapping studies and identify periods of extreme abundance of collared lemmings at Churchill during 1932-90. Monthly temperature and precipitation data are related to the timing of high and low abundance using a response function approach. A strong, yet infrequent, anomaly that corresponds with periods of extreme abundance may demonstrate the impact of an extreme weather event on changing lemming populations. A persistent weather anomaly that corresponds to periods of extreme abundance suggests a weather influence on population fluctuations.

\section{METHODS}

Using both my trapping data from 1980-90 and published and unpublished field reports for collared lemmings at Churchill during 1932-90, years when abundance was far from average and was noted as either extremely high or extremely low were recorded. Yearly reports were compared to estimates over consecutive years so relative peaks or lows could be determined. Usually the anecdotes regarding such 
PEAK ABUNDANCE

LOW ABUNDANCE
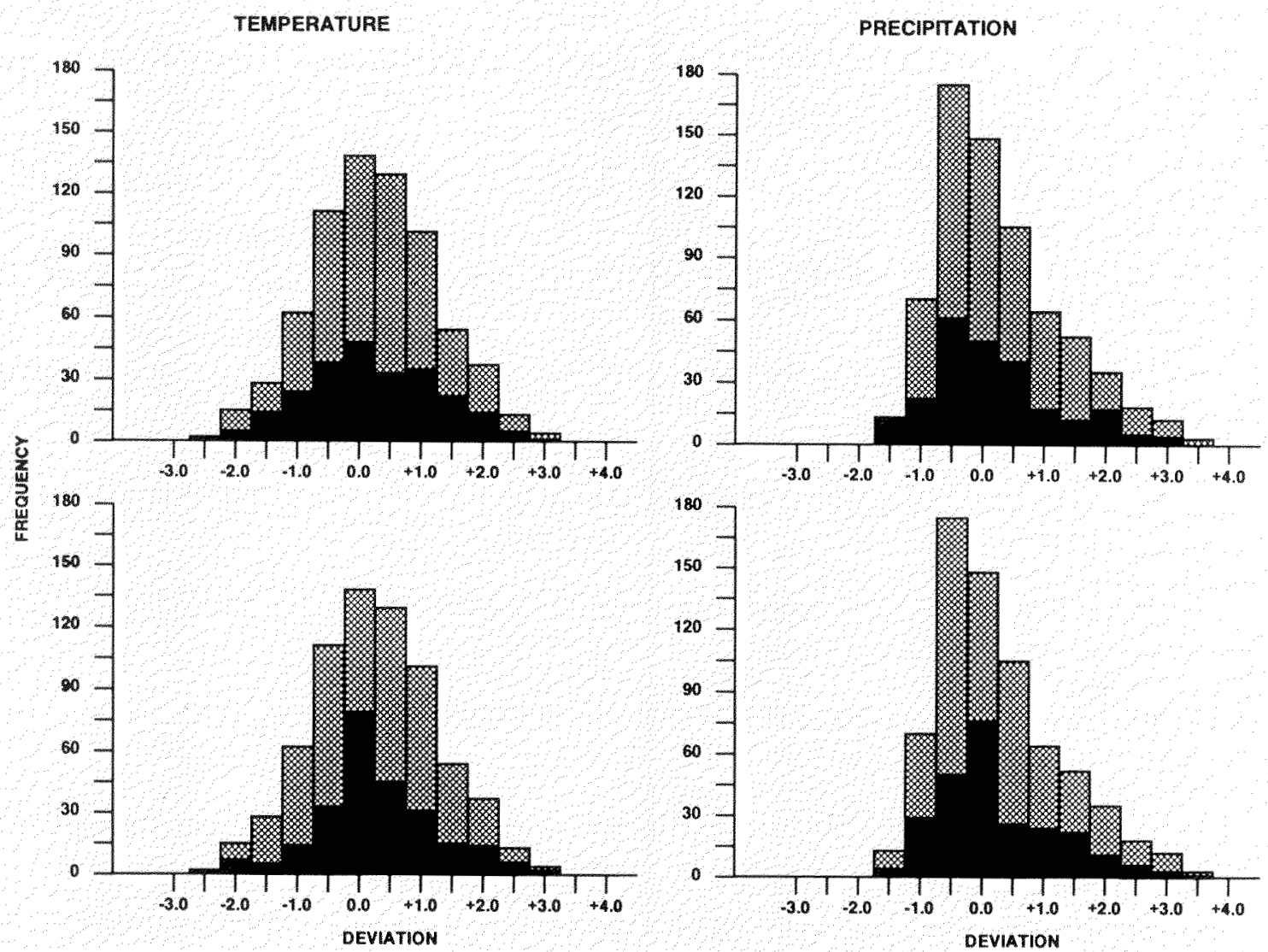

FIG. 2. The deviations of monthly temperature and precipitation at Churchill during 1932-90 (cross-hatched) versus periods of peak and low collared lemming abundance (solid). The (+) and (-) preceding the deviation indicates above and below the average for the 1932-90 period respectively.
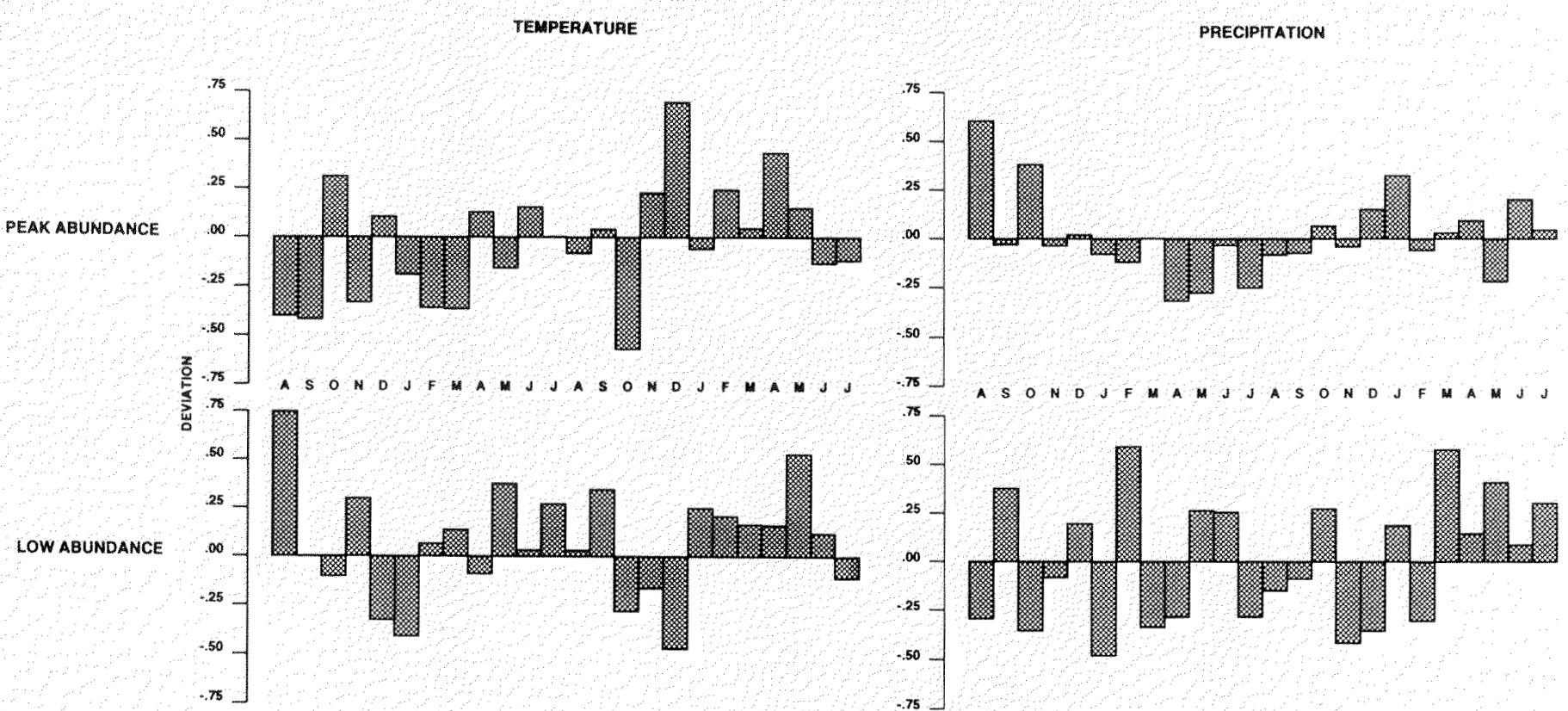

FIG. 3. The response functions (average deviations during the periods of peak and low abundance) for monthly temperature and precipitation auring the 24 months before August of the year of peak or low in collared lemming abundance.

small mammals (Pruitt, 1957; Courtin et al., 1991), although the reduced snow cover in less extreme years is inconsequential (Krebs, 1964; Fuller, 1977) and would not influence cycling. Periods of peak lemming abundance are characterized by a quick freeze-up during fall followed by relatively heavy snowfall or relatively warm temperatures after freeze-up until the snow has accumulated. The periods of low abundance are characterized by below normal temperatures and high precipitation during freeze-up in October and low temperature and precipitation in November and December. 
peaks and lows were conclusive, such as thousands of trapnights with no captures or collections made by walking along and picking up animals because they were so numerous.

Monthly summaries of temperature and precipitation data for Churchill were obtained from the Churchill Weather Office (Churchill, Manitoba), which is located within the centre of the trapping region. The first year of complete weather data was 1932. Product-moment correlations (Sokal and Rohlf, 1981) between the monthly temperatures and precipitations for the $1932-90$ period were calculated to check for interdependence among the variaples. Each weather series was standardized by converting the values to units of standard deviations above $(+)$ or below $(-)$ the average for the 1932-90 mean.

To develop response functions, each data set consisted of the deviations of monthly temperature and precipitation starting with July in the year of extreme abundance and including the previous 23 months. This period should be long enough to include the initial events that could be responsible for either the increase to a peak or the decline to a low in abundance. One data set included the deviations for years of high abundance and the other included the deviations for years of low abundance. Each data set was then compared to the data for the full $1930-90$ period to identify any strong or persistent anomalies corresponding with periods of extreme lemming abundance. The deviations for temperature and precipitation are individually summed for years of peak and low abundances and contrasted.

\section{RESULTS}

No sources were found for the abundance of collared lemmings at Churchill during 1942-48 and 1956-66 (Fig. 1). The following 14 years are known periods of relatively greater numbers of lemmings: 1933, 1936, 1940, 1941 (Shelford, 1943), 1949, 1953 (Smith and Foster, 1957), 1967 (Brooks, 1970), 1971, 1975 (Brooks, pers. comm. 1980), 1980, 1984 (Scott and Hansell, 1989), 1985 (Brooks, pers. comm. 1987), 1988 and 1989 (Scott, unpubl.). The following 14 years represent periods when lemmings have been extremely rare at Churchill: 1931, 1934, 1935, 1938 (Shelford, 1943), 1951, 1955 (Smith and Foster, 1957), 1969 (Brooks, 1970), 1973, 1977 (Brooks, pers. comm. 1980), 1978 (Folk, pers. comm. 1990), 1982, 1983, 1986 and 1987 (Scott and Hansell, 1989). To include weather data for 24 months before a period of extreme abundance, the analysis was restricted to periods of lemming abundance beginning in 1934. Where peak or low periods in abundance occurred in consecutive years, the 24 months up to the first year of the period were used. In total the analysis included ten periods of peak abundance and nine periods of low abundance.

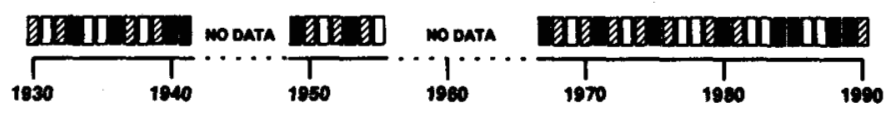

FIG. 1. A summary of known collared lemming trapping studies at Churchill, Manitoba, 1930-90. Years of peak abundance are shown (black) with years of low abundance (white). Years of intermediate lemming densities are cross-hatched.
The variation in temperature 24 months before peak or low periods of lemming abundance does not differ clearly from the normal temperature variation as a whole (Fig. 2). The precipitation has less central tendency and a shift towards the negative (drier) side of the distribution before lemming peaks occur. Periods before a low in abundance have a greater central tendency. Periods of peak lemming abundance are characterized by low October temperature followed by high November and a very high December temperature (Fig. 3). Large extremes in precipitation are also rare in the year before the peak. Periods of low abundance generally have above average temperatures for the first 8 months of the year, which correlate to greater snowfall. Further, periods of low abundance correspond to low October temperature coupled with high precipitation along with low November and December temperature and precipitation. The inconsistent occurrence of other temperature and precipitation anomalies indicates they are probably artifacts of the interdependency among weather variables (Gray and Pilcher, 1983).

\section{DISCUSSION}

The years of low abundance of collared lemmings are noted either one or two years immediately after a peak in abundance and are often two-year events. Multi-year low periods have been reported also by others (e.g., Steen et al., 1990). The occurrence of periods of low abundance may appear irregular because of difficulty in determining specific years of low abundance from (lack of) captures during periods of extreme low density. The reports of double peaks in abundance of collared lemmings for 1940-41, 1984-85 and 1988-89 may be single peaks spread over a winter when researchers were not trapping. For example, the 1980 peak in abundance was noted during December (Scott, unpubl.). Excepting the second year of double peaks, there has been a regular, predictable occurrence of peak abundance of collared lemmings at four-year intervals. However, the density of mature female lemmings during the peak has ranged to around $15 \mathrm{ha}^{-1}$, while the peaks of other species (Scott, 1988) and in lemming density during 1967 and earlier ranged into the 100s ha-1 (Shelford, 1943; Brooks, 1970, pers. comm. 1987).

The predictable occurrence of peaks in lemming abundance indicates that biotic factors probably generate the cyclic mechanism, which cannot relate directly to unpredictable weather variables. However, multiple combinations of extreme temperature and precipitation conditions associated with the onset of winter appear to have a close relationship to population phases. This influence is initially demonstrated where periods of peak abundance are drier than periods of low abundance. The periods of peak abundance are associated with low October temperatures followed by high November and December temperatures and high December and January precipitation. October is the freeze-up period, where low temperatures translate into snow rather than freezing rain. Most winter snowfall occurs in April or May, and thus the occurrence of low temperatures in November and December without a protective snow cover can be detrimental to the 
Extreme conditions (i.e., temperature and precipitation values $>1$ SD from average) around fall freeze-up during 1932-90 correspond to periods of peak and low lemming abundance as ascertained by Shelford (1943) during the $1929-40$ period. The Churchill region is the southernmost extension of arctic tundra and collared lemmings in North America (Scott and Hansell, 1989). The area has undergone a considerable warming of climate since the end of the Little Ice Age (Scott et al., 1988). Currently as a tree-line region, there is a very high annual number of freeze-thaw cycles at Churchill, which are apparently detrimental to collared lemmings as they coincide with non-peak periods. Progressing away from the tree line to warmer and colder regions, the number of freeze-thaw cycles is reduced. A more suitable environment for this species would be at a more northern location or at Churchill under a cooler climate, as existed during the Little Ice Age.

During the $1940-70$ period Churchill had undergone a cooling trend, which reversed during the 1970 s and 1980 s (Churchill Weather Office). The high variability in weather events during the 1970s and 1980 s coincides with an overall decline in lemming density, which has been noted in peak years. It seems likely that the changing climate is causing stress on the population and may have predisposed it to extreme weather events, which are frequent during this transition in climate. Short-term trapping studies should be complemented with an adequate analysis of long-term weather patterns so that an index of weather variability could be used to quantify the stress levels and enable evaluation of populations. In understanding the current status of a population, researchers can evaluate the present behaviour in the proper context.

\section{ACKNOWLEDGEMENTS}

I would like to thank R. Hansell, J. Eger, R. Boonstra and B. Falls for helpful discussions and S. Gilbert and G. Courtin for helpful comments on the manuscript. R.J. Brooks, at the University of Guelph, and G.E. Folk, at the University of lowa, provided unpublished trapping information. Thanks also to the Environment Canada staff at the weather office for their cooperation and support. This study was supported by NSERC, the Northern Scientific Training Program and Boreal Projects of Churchill.

\section{REFERENCES}

BROOKS, R.J. 1970. Ecology and acoustic behavior of the collared lemming, Dicrostonyx groenlandicus (Traill). Ph.D. thesis, University of Illinois, Urbana, Illinois.

COURTIN, G.M., KALLIOMAKI, N.M., HILLIS, T., and ROBITAILLE, R.L. 1991. The effect of abiotic factors on the overwintering success in the meadow vole, Mictrous pennsylvanicus: Winter redefined. Arctic and Alpine Research 23:45-52.

ELTON, C., and NICHOLSON, M. 1942. The ten-year cycle in numbers of lynx in Canada. Journal of Animal Ecology 11:215-244.

FOSTER, J.B. 1961. Life history of the phenacomys vole. Journal of Mammalogy 42:181-198.

FRITTS, H.C. 1976. Tree rings and climate. London: Academic Press.

FULLER, W.A. 1977. Demography of a subarctic population of Clethrionmys gapperi: Numbers and survival. Canadian Journal of Zoology 55:42-51.

GRAY, B.M., and PILCHER, J.R. 1983. Testing the significance of summary response functions. Tree-Ring Bulletin 43:31-38.

GRAY, B.M., WIGLEY, T.M.L., and PILCHER, J.R. 1981. Statistical significance and reproducibility of tree-ring response functions. TreeRing Bulletin 41:21-35.

KREBS, C.J. 1964. The lemming cycle at Baker Lake, Northwest Territories, during 1959-62. Montreal: The Arctic Institute of North America. Technical Paper No. 15.

MIHOK, S., TURNER, B.N., and IVERSON, S.L. 1985. The characterization of vole population dynamics. Ecological Monographs 55:399-420.

PREBLE, E.A. 1902. A biological investigation of the Hudson Bay region. North American Fauna 22:1-140.

PRUITT, W.O. 1957. Observations on the bioclimate of some taiga mammals. Arctic 10:131-138.

QUAY, W.B. 1969. Comparative occurrence of brain colloid deposits in microtine rodents from Churchill, Manitoba. Journal of Mammalogy 50:21-27.

SCOTT, P.A. 1988. Diet and distribution of collared lemmings near Churchill, Manitoba, Canada. In: Students Research in Canada's North: Proceedings of the First National Students Conference on Northern Studies. 399-403

SCOTT, P.A., and HANSELL, R.I.C. 1989. The lemming community on lichen-heath tundra at Churchill, Manitoba. Canadian Field-Naturalist 103:358-362.

SCOTT, P.A., FAYLE, D.C.F., BENTLEY, C.V., and HANSELL, R.I.C. 1988. Large scale changes in atmospheric circulation interpreted from patterns of tree growth at Churchill, Manitoba, Canada. Arctic and Alpine Research 20:199-211.

SHELFORD, V.E., 1943. The abundance of the collared lemming (Dicrostonyx groenlandicus (Tr.) var. Richardsonii Mer.) in the Churchill area, 1929 to 1940 . Ecology 24:472-484.

SHELFORD, V.E., and TWOMEY, A.C. 1941. Tundra animal communities in the vicinity of Churchill, Manitoba. Ecology 22:47-69.

SMITH, D.A., and FOSTER, J.B. 1957. Notes on the small mammals of Churchill, Manitoba. Journal of Mammalogy 38:98-115.

SOKAL, R.R., and ROHLF, F.J. 1981. Biometry. 2nd ed. New York: W.H. Freeman and Co.

STEEN, H., YOCCOZ, N.G., and IMS, R.A. 1990. Predators and small rodent cycles: An analysis of a 79-year time series of small rodent population fluctuations. Oikos 59:115-120.

WRIGLEY, R.E. 1974. Ecological notes on animals of the Churchill Region of Hudson Bay. Arctic 27:201-213. 